\title{
Doing Islandness: A Non-Representational Approach to an Island's Sense of Place
}

This paper presents both an empirical characterization and a theoretical treatment of an island as practice. Through video and ethnographic description we describe and interpret how one kind of islandness is done. Thus we understand islandness corporeally, affectually, practically, intimately, as a visceral experience. Basing our conceptual treatment on the non-representational idea of dwelling we approach place as a kind of practice. We view the key performances through which an island becomes such as practices of incorporation. Inbabitants, we believe, incorporate a place not by way of mental design or blueprints, or by way of signifying comparisons and juxtapositions, but rather by sheer practical, creative, skillful engagement with its affordances. Thus we understand the practices of an islander as someone who assembles together an island by way of making use of whatever is at hand, solving going concerns as they present themselves.

Keywords: Islandness; Islands; Sense of Place; Non-Representational Theory; Visual Methods

Visualize a billboard ad along the side of the highway, as you zoom by. Perhaps visualize the very last one you saw, on your way to the office. Can you tell me what it said? Did you slow down to read it, to take it all in?

Visualize a bulletin board now. Its cork-like texture. Its multiple colorful thumbtacks. The panoply of old signs posted weeks and months ago, now buried underneath newer ones with less rugged edges, with more hope of catching your attention. Visualize it hung up on the paint-yearning wall of a small island ferry terminal. Well, "terminal," hardly. More like a garage of sorts: stuffy and unkempt inside, full of old cheesy furniture and bad plumbing, and surrounded by dusty cars and old bikes on the outside.

Visualize your attention not needing large letters or flashing neon lights. You're close enough to read, you live near enough to care. And the ferry's unhurried pace has gifted you time to read. "Mystical escapes through sound and vibration." "Looking for a ride to Victoria from the 7:40 ferry." "We will work with dreams, music, movement, ritual, and interpersonal relations." "Boat for sale." "Local BC shrimp." "Guided kayaking adventures." "Giant Garage Sale." "Run away to Gabriola: Cozy retreat for rent." "Drivers beware: Newborn fawns on the road this month." Everything seems to be moving differently around here, on its own pace. Old clothes re-circulate. Local delicacies stay close to home palates. Outsiders escape and retreat here. Locals hitch rides, gingerly dodge deer, and float together on kayaks and ferries. 


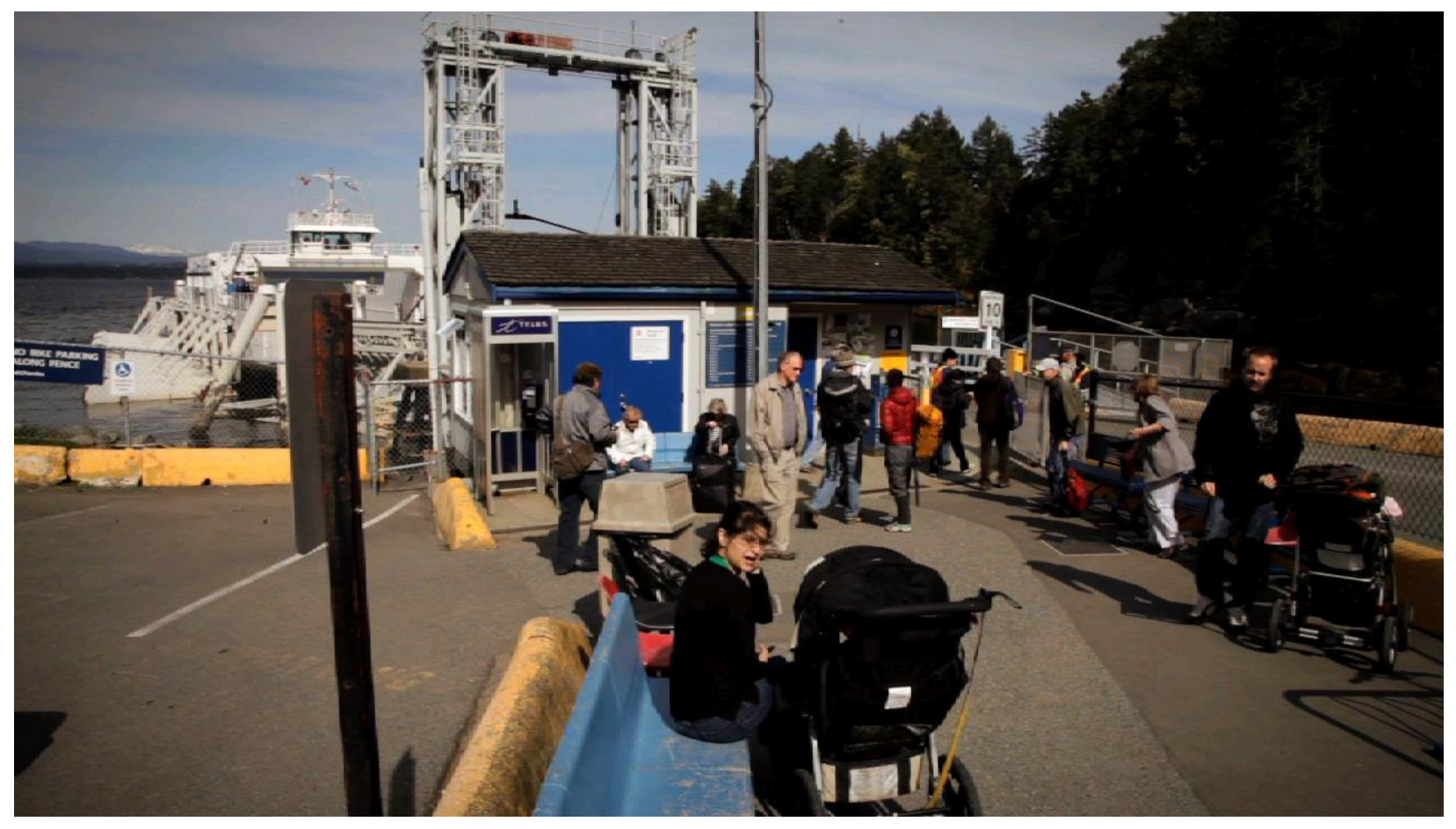

Picture 1: The Ferry Terminal: If link malfunctions, view at: http:/ / www.youtube.com/watch?v=G_AEOECy_5k

As the ferry docks and her traffic unloads, the foot passengers waiting to board look at the drivers heading uphill to see who is coming. Visualize a few smiles and waves, as the deckhand attending to the gate seems more focused on catching up with his buddies going to town, than on directing drivers or holding footsies in place. After all, they both know how to find their way. Visualize Julie, suddenly arriving to the waiting area, scrambling out of her car, as the insistent "ping" reminds her to buckle up a seat belt she doesn't need. "Is anyone going by the library in Nanaimo?" she hollers at no one in particular. "I forgot to return this book, and it's due today," she pleads. Someone you don't know picks it up-they're going downtown anyway. Julie thanks the couple with a hug. Even books circulate differently around here. Visualize how islanders do that. Visualize what this way of moving does to a place, to an island.

Some are big and others are small. Some are curvy and others are flat. Some are dark, and others are bright and shiny. Some are friendly and others are reserved. Some are highly sought-after, and others are abandoned and forgotten. Some are easy and others are impossible to win over. Indeed, they have so little in common with one another that to speak of them all simultaneously is but futile. $\mathrm{I}^{1}$ am speaking of islands, but I might 
as well be speaking of something else, like women or men—as my rhetoric teasingly adumbrates. Indeed the field of island studies shares an important characteristic with that of gender studies. Their objects of inquiry are so numerous, so heterogeneous, that to utilize an overarching category—such as "islands," or "men," or "women"- entails miring the field in an impassable quagmire of qualifiers, subcategories, exceptions, and scare quotes ${ }^{2}$. In order to unhinge sweeping binary oppositions and undo master statuses long locked in popular discourse, many gender studies scholars have by now agreed upon the worth of a simple but powerful expedient: rather than map differences and similarities between men and women writ large, they find it makes more sense to scrutinize how those very entities come to be in their multiple forms through diverse situated practices $^{3}$. Island studies scholars have not adopted, or at least not as widely, a parallel strategy. In an attempt to foster the diffusion of such ideographic perspective, in this paper I present both an empirical characterization and a theoretical treatment of an island as practice-not islands plural, or even "the" island. In fewer words, this is a story about how one kind of islandness is done.

I write from a minority position of sorts. Even though no official data exist on the topic, it seems to me that most of the scholars who regularly contribute to the field of island studies are full-time mainlanders, part-time islanders, or residents of largely populated islands. My perspective is unique in that I dwell on a small island full time. I point this out not in order to assert some kind of authentic claim to island identity, but more modestly in order to identify my way of knowing, indeed my very place-based nissology ${ }^{4}$. As a full time small islander I am in a position to understand islandness corporeally, affectually, practically, intimately, "as a deeply visceral lived experience" 5 . This one of the reasons is why I do not employ here popular and useful characterizations of the island as a "mental map" or a "construct of the mind"7 and the imagination. ${ }^{8}$ For me, my island is more of a "going concern" many-less as an essential property of all islands, less for the typical qualities that seduce outsiders imagining islands from a distance (e.g. escape, utopia, exoticness, boundedness, etc.), and more for the excruciatingly mundane, but not less distinct, embodied experiences that islandness demands and affords. Not only does my position differ from the wider currency in island studies, but it also accounts for the coherence of the theoretical perspective I embrace, one that is based on the idea of dwelling ${ }^{10}$. 
A dwelling perspective approaches place as a kind of practice ${ }^{11}$. For Michel deCerteau ${ }^{12}$, for example, practices—or the concrete and embodied strategies and tactics through which we put things into use-are directly constitutive of the lifeworld. For David Seamon ${ }^{13}$ it is practices of movement, rest, and encounter which constitute our lifeworld. And anthropologist Tim Ingold ${ }^{14}$, drawing from broader phenomenological ideas, suggests that the key performances through which places become what they can be are practices of incorporation. Inhabitants incorporate a place by sheer practical, creative, skillful engagement with its affordances. Thus a dwelling perspective is the perspective of a home-maker, a wayfarer, or a weaversomeone who assembles together an object (such as an island) by way of making use of whatever is at hand, solving going concerns as they present themselves.

Suggestive ideas employed in this paper such as dwelling, wayfaring, and related metaphors and concepts have lately come to be grouped under a relatively novel theoretical apparatus in geography, which for lack of better terms has come to be known as non-representational theory ${ }^{15}$. Non-representational theory, or non-representational theories or ontologies, generally rely on the basic belief that realities are constituted through practices or performances ${ }^{16}$. Chief amongst these practices are those that pertain to movement. Whether aided by engines or not, whether planned or unplanned, solitary or accompanied, human or nonhuman, movement has ontogenetic qualities. This basic idea, when applied to place, has generated a powerful understanding of spatiality as relational, affective, sensual, and embodied. To put it in simpler terms, a place is what its place-makers—-humans or non-humans—-do. It is this idea that I apply to my understanding of sense of place on Gabriola Island. ${ }^{17}$ In a nutshell, my argument is that sense of island place, or islandness, is an outcome of what islanders do, and in particular of how islanders move ${ }^{18}$. I do not disagree with the view that islandness is a "multicultural phenomenon"19, but I am less keen on defining what it is and what it encompasses than I am on describing some of the situated ways in which it is done.

Ethnographic description of everyday practices cannot be an unproblematic procedure to someone claiming to adopt an epistemology that is non-representational. Therefore, in order to make the feel of my island known to you I attempt not to represent but to reveal, to enliven, and animate ${ }^{20}$ my mundane island spaces, through a (hopefully) evocative and impressionist rendition strategy that draws from traditions such as 
lyrical inquiry ${ }^{21}$ and arts-informed research ${ }^{22}$. After all, for anyone claiming to view banal doings as transformative, generative, or poietic and then to surrender representation to formulaic impersonal characterizations would be at best unimaginative and worst hypocritical. So, by following the inspiration of Kathleen Stewart and her work on the poetics of a "space on the side of the road" in US Appalachia ${ }^{23}$, I invite you to experience my island, to grasp what it feels like, to make sense of my place. I do so through my own words and through the images and sounds collected by my artist-collaborator: (anonymous for peer review). These images render sense of place and movement in a way in which words alone would fail ${ }^{24}$. Moving images and sound will play when you click on the photos interspersed throughout the online version of this essay.

The knowledge upon which this paper draws is reflexive and ethnographic. It is reflexive in the sense that it draws from my kinesthetic experiences and practices ${ }^{25}$ as a resident of my island for over one year. Not much time at all, admittedly, but I do believe that it is precisely during the first one or two years of dwelling in a new place that a certain acuteness of observation and introspection is at its best, before things become too taken for granted (to boot, I also bring to the background of my reflection seven years as a full-time resident of another island, Vancouver Island). Secondly, I draw knowledge from a three-year ethnographic study of mobility on the Canadian West Coast. Through that study ${ }^{26}$ I delved in great depth—through about 400 interviews and over three years of participant observation-into the practices and politics of islanders' connections and disconnections with the rest of the world, and came to the conclusion that islands are relational spatialities grounded in unique kinesthetic performances. Not unlike I do here.

\section{The Seaplane Pier}

Picture yourself undulating, left to right, left to right, with every wave, every ripple bumping into the floating dock. You catch your feet shuffling, your centre of gravity shifting, as the damp, wooden walkboard oscillates with you and the ocean, as if it were inviting you to move, compellingly, along with them. Picture yourself feeling the urge to fly_ off to the mainland, on to the big city airport, on to far, bigger places. Your nerves telling you it's time to check in, weigh the baggage, grab your boarding pass, load your luggage, and take off. 
Picture the wristwatch you don't carry anymore hollering at your conscience for your attention. It's time. Another second flies by. It's time.

Picture your skin curling up with every waft of ocean breeze, as if the water's cold breath were whispering in your ears. So you unzip your carry-on. You unfold a carefully packed sweater and hurriedly slip it on. You are alone. You have a seaplane to catch. You have your island, your home, to leave behind. It's only a few days away, but picture yourself aching in anticipation of your return. You feel the pain as if your stomach gasped for island air with every puff you take. But every breath is a struggle—as if you inhaled to devour more and more of the tasty, moist ocean particles lingering in the atmosphere. Picture every one of those tide-scented particles jammed in your throat, weighing you down, as if with each gasp you bore the progressively unbearable, expanding weight of island gravity.

"Where in the world is Harry?" Twenty minutes to your flight. No one there to check you in, no plane at the horizon. Picture yourself dialing his number in anxiety. Only to hear his forgotten phone ring inside the shack on the pier. No one there to answer it. Picture anxiety making space for dread. Dystopian thoughts assault your mind and body. They can't be late. You can't be late. Another second goes by, mercilessly. And another. And with every feeling that it's later, and later, picture yourself exiting island time, getting sucked into the vortex-like timescape of the mainland. Picture yourself breathing faster-no longer to absorb island air, but to exhale its rhythms. To let it go.

And there's Harry. Fishing rod in one hand, bucket in the other. Picture him ambling down the dock, smiling, as he babbles a word to Jenn, parading alongside him, strolling her suitcase. T-tock, t-tock, t-tockher suitcase wheels utter while rolling on the dock, as they hit the gaps between each plank of wood. Picture Harry and Jenn greeting you. Calmly. Still on island time. "You're here early, today"-you're told. You've got somewhere important to go, you answer. "Oh yeah, that conference overseas you were telling me about"Jenn acknowledges. 


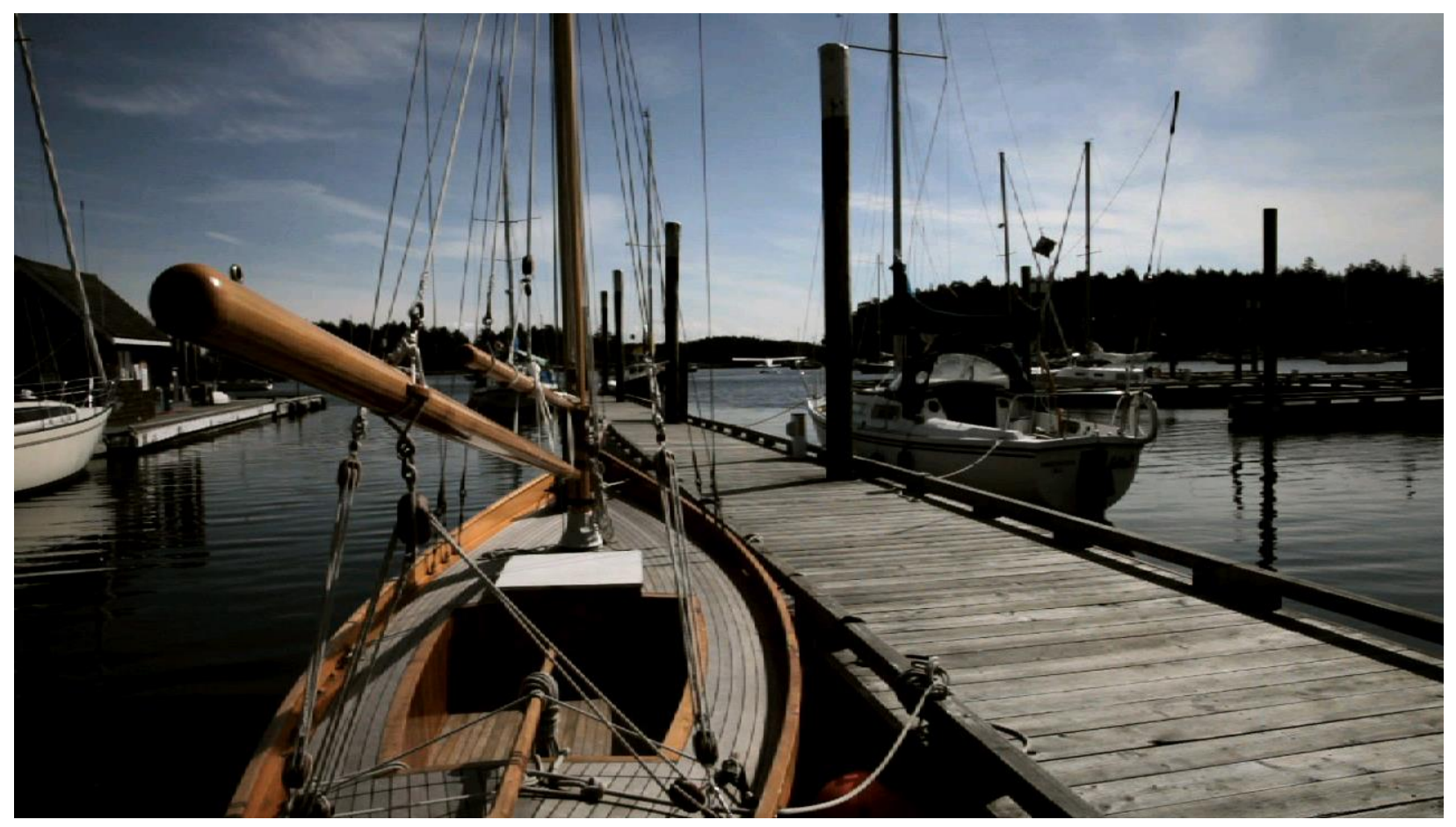

Picture 2: The Seaplane Pier. If link malfunctions, view at: http:/ / www.youtube.com/watch? $v=t 2 Z a f \_e d V v Q$

Picture having no boarding pass to collect. Picture Harry eye-checking, then lifting your suitcase with one hand instead of weighing it with a scale or scanning it with x-rays. "Twenty-two pounds," he guesses. Picture having to show no ID because Harry and your kids play soccer together. Picture John, the seaplane pilot, apologizing to you and Jenn upon arrival for being "a couple of minutes late." Picture having no glossy magazines to buy on your way to the gate. Or having no gate at all-indeed, nothing but a big watery abyss separating the dock from the five-seater. An abyss dismembering and yet connecting your island with the rest of the world. Picture the raucous engine of the plane drowning out your melancholia, as you stretch your neck to catch a last glimpse, for a while, of your island.

\section{On the Road}

Imagine a road as twisted as an islander's imagination. A road as scrumptious and as uneven as a piece of Gruyere cheese-with each pothole collecting the changing signs of the seasons: leaves, snow, water, and sand as the year goes by. Or a road as enchanting and as narrow as a deer trail—with Bambi and his siblings curiously ogling at you as you drive by, calmly munching salal on the roadside. Or a road normally so lonely that whenever five or more vehicles appear all at once, even children realize that the ferry must have just let 
out. Or imagine a road as intriguing as a piece of woven cloth stitched together maniacally, with some threads as smooth as silk interlacing others as coarse as sandpaper, together bending and winding in a quixotic pattern made of twists, cracks, humps, and bumps.

Now imagine yourself driving on those island roads. While on the mainland you roll in your "town car"- - the nicer, newer set of wheels (not too nice, however, as never trust those "vandals" out there!). But on your island you cruise on your beloved "island car," the vehicle you keep exclusively on the rock to shuttle from the ferry terminal to your home and vice versa, and everywhere in between. Your island car is not just an automobile; it is an embodiment of island roads.

Imagine the moss growing on its bumpers. Imagine the random pieces of driftwood in the trunkwhich one day you will actually use for that project you set your mind to. Imagine the floorboard ripened with sand, gravel, twigs, and leaves. Imagine the dashboard littered with ferry tickets, to-do lists for your trips to town, and a ferry schedule that you have not consulted since a Liberal was the Prime Minister. Imagine the faded out stickers adorning it: the "Slow down: This ain't the mainland" one. The "Wild salmon don't do drugs" one. The "I losers" one. And the "Save our ferries" one.

Imagine stepping on the gas of your island car to reach the speed limit of $50 \mathrm{~km} / \mathrm{h}$ in less than twenty seconds. Then wondering what time it is. Time to follow patiently the senior driving $10 \mathrm{~km} / \mathrm{h}$ below the speed limit in front of you? Time to rev it up to $70 \mathrm{~km} / \mathrm{h}$ and cope with the anxiety that your neighbors will lament your speed fetishism in the weekly island paper? Or time to make that ferry and throw caution to the wing, alongside with everyone else on the island?

Imagine waving at cars driving the opposite direction, regardless of whether you know the driver. Imagine using one or two fingers if you don't really know them, the entire hand if you do, and even smiling and waving if you call them friends. Imagine respecting the social norm that hitch-hikers must be picked up, almost at all times. Imagine feeling the need to apologize to hitch-hikers in circumstances when you just can't pick them up: you raise your hand over your head to show them you're full; you point right or left by bending your wrist to indicate you're about to turn off the main road; you curl your index and thumb to explain you're just going a short way. But you never point to your watch—as if you carried one-to excuse yourself for 
being in too much of a rush. If there is a ferry to catch, after all, they are in a rush too. And if there is no ferry to catch, why be in a rush?

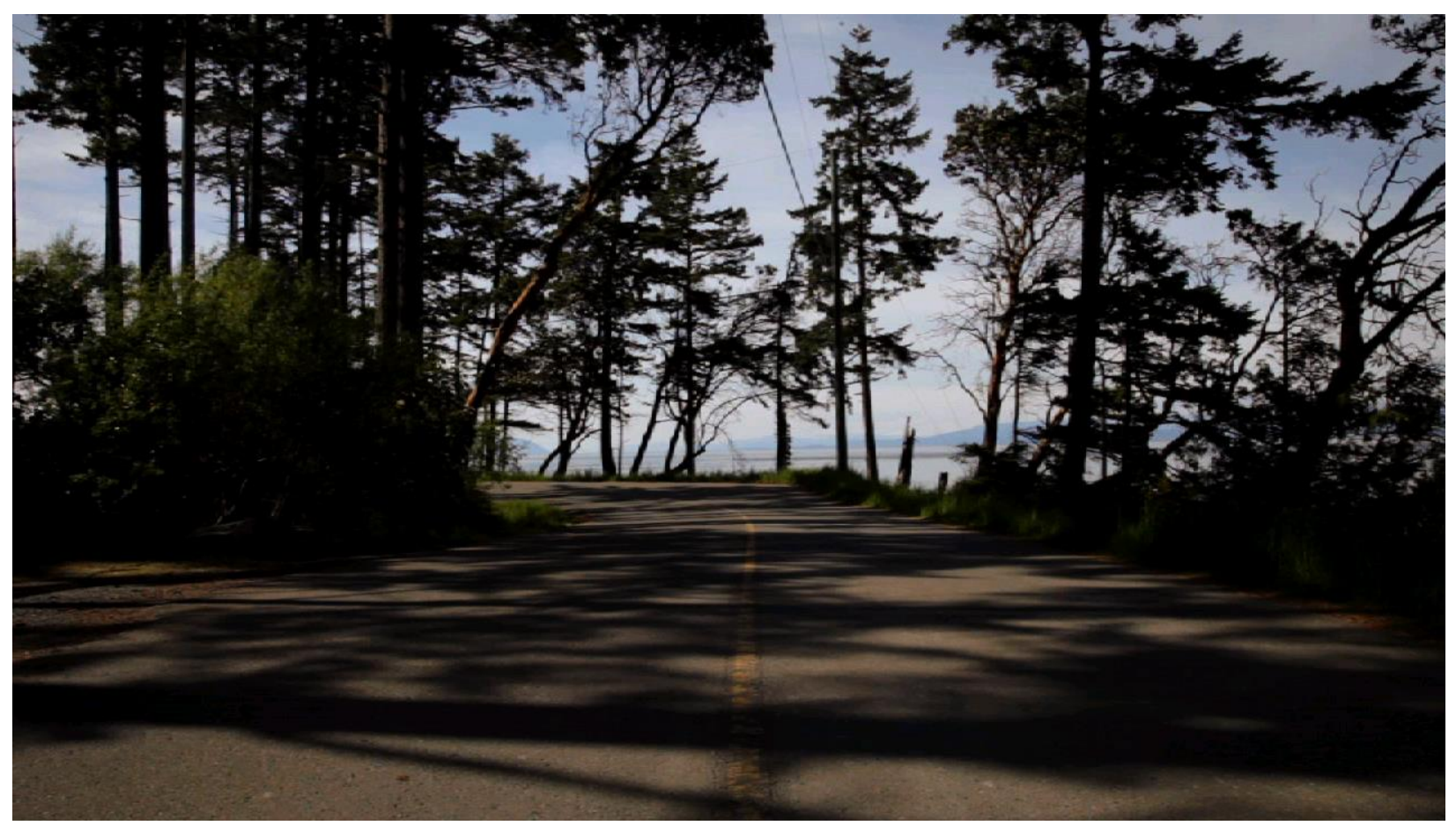

Picture 3: On the road. If link malfunctions, view at: http:/ / www.youtube.com/watch?v=9SE-Y4Oq_GE

And then, imagine yourself finally getting a new car. And realizing that everyone on the road, for at least a month, will think you're a tourist and greet you as such, or simply won't.

\section{At the Beach}

You won't find much sand here. Drumbeg is a prototypical Gulf Island "beach;” a secluded cove hugged by massive conifers and held together in one piece by sandstone ledges, laddered like layers descending toward the ocean water. Spheric, penny-sized, shiny pebbles succumb to your footsteps, sounding like hushed maracas as you traipse along the shoreline. Gentle but brutally cold waves both invite you to and warn you against dipping your feet. You won't find beach balls bouncing around here. You will find kelp with gas bladder balls so big that you could almost use them as bottles, as the First Nations used to do. You won't find the raucous blare of boom-boxes here, or the frolicking of teenagers chasing their own tails in a frenzy. You will find rock benches. Often empty, at times anchored down by the pensive body of an older man or woman 
in search of companionship with nature, or by the ravished presence of an absent mind lost in a book or in a half-completed oceanscape painting.

You won't find sun here. At least not too often. Turbulent clouds, long and slim clouds, streaky clouds, overcasting clouds, puffy and billowy clouds. You will find those. Often. They won't discourage the one or two kayakers from gliding away toward the seal colony off Kendrick Island. They won't obstruct the couple of cabin-feverish souls strolling on the other side of the bay, gazing with one set of eyes at the distant coastal mountains on the mainland. Or at their young children learning the art of balancing on a washed out $\log$ while eyeing pieces for their next driftwood fort. You won't find much swimming here, though there is some. The swimming of enthusiastic dogs chasing a tennis ball as far as they can. The sloshing of toddlers prompting everyone to wonder how they can withstand the chill. The splashing of young and old alike, skipping a flat stone on the surface of the water, three, four, five times, till a ripple sucks it in.

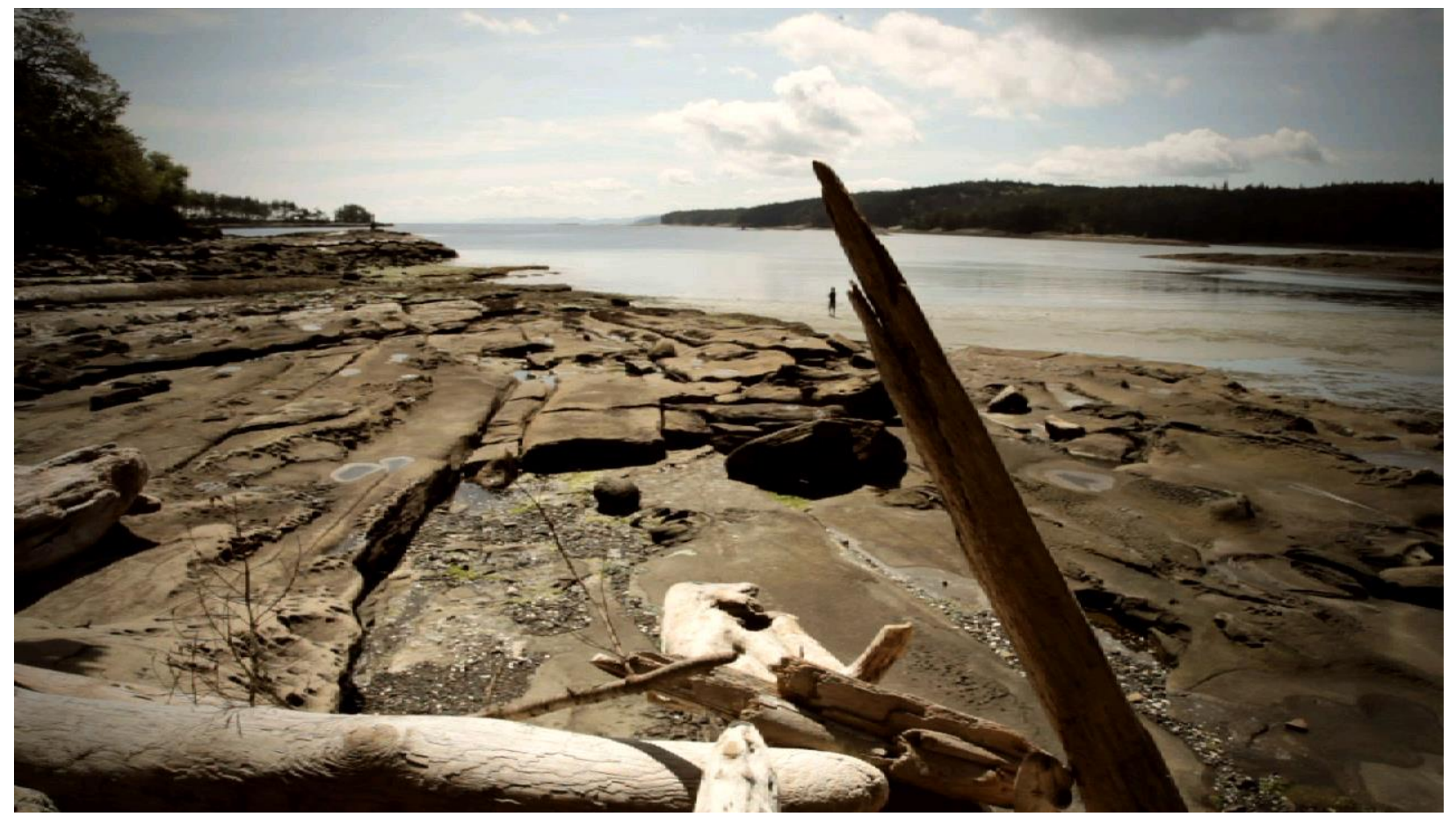

Picture 4: At the beach. If link malfunctions, view at: http:// wwn youtube.com/watch?v=cdDKM-Q7N1I

You won't find sex here. You will find purple starfish huddled so tight, piled on top of one another so intimately, that you will think they are either in orgiastic love or they have found a way to bear with the cold ebbs and flows of the water. You won't find many bikinis, either. Skimpy beach fashion has given way 
to colorful gumboots for women and hiking shows for men this year. And last year. And the next. But no one cares about looking the part, since eyes have so much more to fixate on. So, you will find yourself ogling at daring skiffs challenging the riptide at False Narrows. You will find yourself scoping for traces of a long sought-after Geocache. You will find yourself smiling at the playful dance of geoducks squirting at each other as in some kind of battle you don't want to get caught in betwixt. You will find yourself dissecting each island from your view—Kendrick from Valdes, Valdes from Mudge, Mudge from Link, Link from DeCourcywith a surgeon's eye precision.

You won't find sales here either. No coconut, no toys, no margaritas, no grilled shrimp, no snorkeling gear. You won't find umbrellas — of either the type used to fight the sun or the rain. You won't find beach chairsOr ten square feet of beach for rent. You will find parking space, though. You will find Steve and Kendra, who are out too today. You will find a corner for a picnic — a corner so wide that for anyone to sit as close as 50 feet to it would just be insolent. You will find time to wonder if that spot of white stuff is sand that has magically appeared, or a heap of broken oyster shells. And you might even find a way to complain about some of this—not warm enough, not quiet enough, not alone enough, and how about those nasty invasive species: Scotch broom and tourists alike.

\section{From the Water}

Envision your island from the ocean water, your ocean water. Envision it as your journey to the mainland comes to an end, as your seaplane pilot reassures you not much has been going on since you left. Envision it as a dark green wall, puffy, and shaggy from a distance. Envision it as the tree branches get edgier and the trunks become brighter as you fly closer. Envision it as you fly even closer, so closer you could almost hear the seagulls if the engine wasn't so loud. So closer you can recognize the blue tarp on the Wilsons' roof, the large windows on the MacKenzie's house, the steep and windy staircase to the shore right in front of that new house that was just built last year. Envision spotting driftwood and using it to gauge the tide. Envision, as you step off the plane, hearing from your fellow passenger that "it finally smells like home."

Envision your island from the snug seat of your kayak. Gripping the paddle with your cold hands, you slow your stroke to see things better: "Is that a seal or the tip of a submerged log?" Suddenly it snorts 
and plunges underwater, and your doubt dissipates. Envision fellow islanders out on the water. Some with their aluminum boats, angling, others on their sailboat, aiming for nowhere in particular. As the tide recedes your island becomes closer, and the smell of algae becomes more pungent, like spinach left to rot on the sandstone. Islands promise a sense of closure-demanding an encompassing experience of them by way of circumnavigation. That is, until you have to paddle your way around. That is, until you envision that slowing your pace, allowing the current to cuddle your boat, gives you a more patient vision. It's a twofold sense of openness and closure earned in measure of enumerating moments of quiet, in losing the count of oyster catchers that have flown by. Envision the sun glittering on the water but feeling too damn cold to romanticize about it.

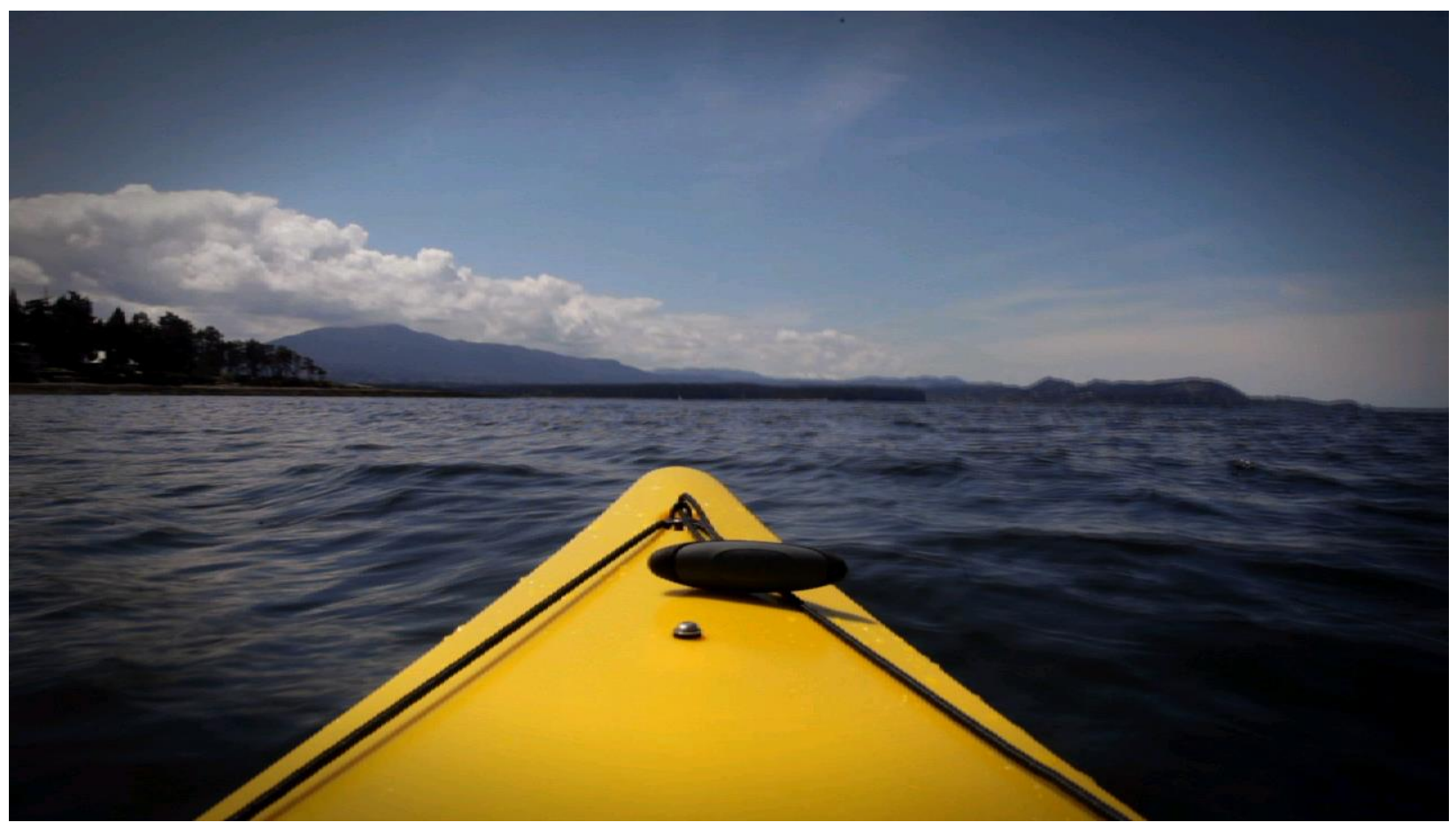

Picture 5: From the water. If link malfunctions, view at: http:/ / www.youtube.com/ watch? $v=p P 2 K N M e d w K w$

Envision your island from the bow of your ferry boat. Steadily aiming towards port. Imagine letting your mind wonder not about the finiteness of your rock, but about its mundane fragility. Where is that plum of smoke coming from - is it a wildfire? How come the ferry is always late when you're in a hurry? Is that a plastic bottle sitting on the shore? How could they have given a permit to those people to build over there? And why do they think that an ocean view gives one the right to cut down so many trees? Envision having 
the militant courage to answer a tourist question the way you really mean it: "You can drive around the island in twenty minutes, but you could bike around it in one hundred minutes, and yes, it's five times better."

Envision how your island might look from the water to a visitor. Utopian. Romantic. Remote. Secluded. Protected. Labile. Cozy. Impractical. Monastic. Finite. Small. Controllable. Now envision how your island might feel to you as an islander. Like your well pump needs a new filter. Like a new fence needs to be put around your garden if your deer are ever to leave your veggies alone. Like some space needs to be found for a larger parking lot at the ferry terminal. Like the new trails still to be traced through the park need volunteers. Like that bus route application with the regional district needs volunteers too. Those are the glimmers of island life you envision as an inhabitant: not abstract spaces of possibility, but concrete places incorporated into your habits, to be made and re-made, by you and your neighbors. Envision not islands from the mainland, or from an island's own highest peak, but envision your island from your water and your shore, as you labor to paddle closer to your home.

\section{Around the Village}

Someone once said that you know you're an islander when it takes you two hours to go to the village to run an errand, as you have to stop and visit with everybody you meet. That might just be the blessing and the curse of getting around an island, they say: you know everybody, and everybody knows you.

On Gabriola Island the village mainly consists of a semi-circular mall. A mall, someone once said, that is the largest of the smallest wooden malls in the nation. The grayish brown cedar walls give way to a dark green jagged roof, shaped in irregular dome-like angles. Cedars and firs surround the building on its northern, southern, and western sides. On its eastern side are the gas station, the bank and insurance place, the small theater, Robert's Restaurant, and a handful of coffee shops and retail stores. The village square proper hosts the food store, the pharmacy, two coffee shops, two retail stores, two unoccupied sites, and the local real estate company office. So, yeah, it can get busy. Someone once said that if Gabriolans were ever in the state of mind of installing a traffic light, this is where it would go. But for now this is more modestly the place where the only marked crosswalk can be found. And that alone can be a difficult task to negotiate for most. 
Someone once said that you know you're an islander when you come to the village to take a break from solitude, and when you go to the mainland to re-learn to appreciate the solitude of your island. Granted, you can find almost everything you need here and you shouldn't need to go off island much. Goods of all sorts—necessities and treats—circulate here daily. And dangerous cargo arrives here too, once a week. So, whether it's propane or gasoline, a cappuccino or a hippie dress, you will find it here. Unless you need something fancy, that is. Like a toy made in China. Or a Starbucks coffee. Or a piece of IKEA furniture. Someone once said that you can buy those things when you go on holiday.

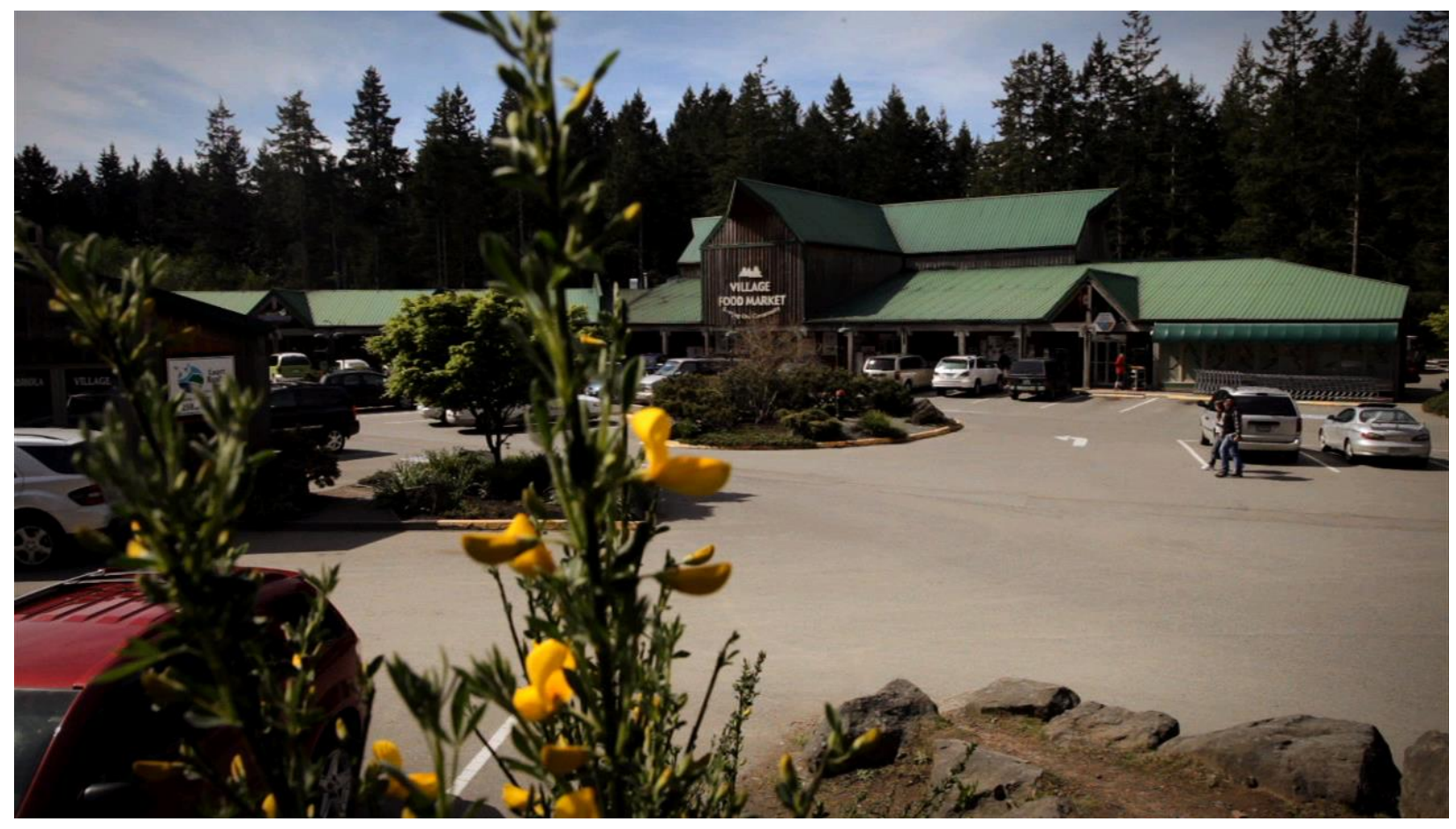

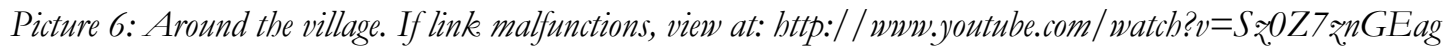

I was once told that most island cars don't need a rear gear. You only really need one if you drive to the village. And even then, they say, you don't have to know how to parallel park in the village. It gets busy, though. On Saturday afternoons you might actually have to look for a parking spot. And on blackout days everyone comes here to talk about the outage and eat at Robert's- they have a generator there. And good pie that begs for an excuse. Someone once said it's just the best thing when the power goes out. Even though cars can still work, many people, for some odd reason, just take to the streets on foot or bike, and treat themselves to this or that. It's like a snow day for grownups, they say. 
Someone once said that you know you're an islander when you don't know how to give directions to tourists down at the village. "Excuse me, where's Gabriola Sands Provincial Park?" They ask. But you have no clue, because to you it's just Twin Beaches. Or perhaps official street names and numbers elude you, and you find yourself telling tourists to turn right "at Arbutus," or maybe turn left where so-and-so used to run a barber's store out of their garage.

Someone else once said that the village is also just about the only place where north-enders and south-enders meet. Regardless of the fact that it would only takes twelve minutes, driving all the way to the other end to just visit someone, well, is just too much to ask.

\section{Island Dwelling}

Now that you have envisioned my island, imagine how we, inhabitants ${ }^{27}$, can make sense of it. Gabriola is first and foremost a place to be lived, to be engaged. Its islandness emerges from the ways inhabitants act, from the unique textures of place, from the ways these textures affect us and the way we affect them. Islandness, from this perspective, is thus less of an abstract property, less of a construction or a symbolic source of identity ${ }^{28}$, and more of an affective experience and practice. Royle ${ }^{29}$ remarks on how difficult it is to establish what an island is in abstract terms. Is a continental island like Australia an island? Is crowded, cosmopolitan, connected Manhattan an island? Is a rock appearing in the middle of a bay at low tide an island? — he ponders. As long as these questions require definitions of what an island or "the" island is in abstract terms, and then judgments over how particular tokens represent the general qualities of said being, islandness remains a representational entity. But as soon as we transform the question-from the notion of "what is an island?" to the practice of "how do you do your island?"-islandness changes from a representation inside our heads to a set of tasks unfolding in front of its inhabitants. ${ }^{30}$

This Gestalt shift in the way we understand islandness demands we view inhabitants and islands as one and the same. Both places and place-makers are nothing without the relations that constitute them. Such an ecological view implies that islands must be examined and comprehended in the context of their inhabitants' experiences and practices. As well, it implies that islanders' livelihoods are "the condensations of histories of growth and maturation" 31 within their fields of social and material relationships, that is, within 
their islands. Such non-representational and relational thinking moves us to consider the characteristics of islands and islanders not as expressions of general properties, but instead as generations taking form in the course of activities within island places. In sum, rather than what asking what islands are, we could be asking ourselves what islanders do and bow they do it: how do they shape their places through their practices, perceptions, relationships, and skills? How do their places come to be through their unique "ballets" of movement, rest, and encounter? ${ }^{32}$ How do they incorporate the unique material features of their islands into their livelihood? Ingold calls this theoretical orientation a dwelling perspective.

From a dwelling perspective we may view islandness as the system of relations constituted by the multi-sensory engagement of inhabitants in their island environments. Such sensory engagement is not only a form of perception of place, that is, of something pre-existing corporeal awareness. Rather, because it is informed by and through movement, rest, and encounter, such sensory engagement is also a process of mutual generation, of constitution, of transformation. Islandness is, therefore, not simply the sense of place typical of islands, but also the multiple ways through which relations amongst inhabitants, and between islands and their dwellers, are practiced ${ }^{33}$. Such organic understanding of islandness is the active and creative unfolding of social and material rapports, an unfolding through which islandness emerges in multiple shapes, each shape in relation to the connections that give it rise. Islandness on Gabriola, after all is distinct from islandness on Vancouver Island, and both are quite different than islandness in Jamaica or Hokkaido. Like place, or the environment in general ${ }^{34}$, an island's islandness is a relative term, relative to the doing and the doers whose island it is.

Once we understand islandness as a type of situated affect or feeling ${ }^{35}$, islandness can then be examined in concrete contextual detail as a "mode of active, perceptual engagement," 36 a way of being in touch with your island. Islandness gives form to your island. In other words, the "meaning" of your island resides in its very sense of place. It is the shape taken by how you you dwell on your island, by the ways you have become socialized to understand and appreciate its sounds, sights, textures, flavors, and scents, by the ways inhabitants' sensibilities may differ from others', by the lessons and intuitions they have acquired in adapting to their place, by their orientations to movement, rest, and encounter, their speeds, and rhythms. 
Thus the life of your island is the sum total of the sensations it gives rise to, the cumulative incorporation of those feelings carved into its soils and shores, and the embodiment of its affective spaces on its dwellers.

A dwelling perspective is based on the idea that every organism, persons included, is immersed into the lifeworld as an inescapable condition of existence ${ }^{37}$. From such immersion and the relations that emerge "the world continually comes into being around the inhabitant, and its manifold constituents take on significance through their incorporation into a regular pattern of life activity" ${ }^{38}$. Ingold contrasts this view with the "building perspective" typical of constructionist, structuralist, and Marxist approaches, according to which people live in a society or culture for which meanings have been constructed and to which meanings have been attached, and it is these meanings that must be recognized and reconstructed within their minds before individuals can act. Of course these theoretical perspectives have their value and in invoking them I do not intend to dismiss their validity, but rather to utilize them in order to contrast the uniqueness of the present perspective and better elucidate it.

In fact, the "straw man" of my argument thus far has been that the received view is such that the notion of an island must first be identified before islandness can be understood. Such received view is typical of other common arguments in the social sciences. For example, sex must first be identified before gender can be understood. And, in another common example, abstract space must first be conceived before a place can be made significant and engaged. The non-representational genes of the dwelling perspective, instead, argue for a different and somewhat less intuitive position. From such perspective the world must first be dwelled within, before one can take a view of it, and from it. In the context of my argument on islandness, your island must then first be dwelled within before islandness can exist. Here is what I mean.

Like any other place, my island is something that is always going on. An island's features-from its tides and currents to the coming and going of its ferries and its dwellers-never cease to move. These movements and the encounters they generate constantly generate my island's sense of place, without detracting from a sense of belonging ${ }^{39}$. From a lazy Sunday afternoon walk on the shoreline to a busy morning ferry lineup, mobilities are the very processes through which my island's islandness takes place. It is through movement, as well as encounter and rest, that inhabitants generate sense of island place ${ }^{40}$. Without 
necessarily altering the shape of our island ${ }^{41}$ these mobilities co-opt ${ }^{42}$ the material features of place to serve our lifestyle purposes. Even the very "separation" of our island from the mainland or a much larger island like Vancouver Island, and the forms of mobility such "separation" entails, is crucial to our islandness ${ }^{43}$. Indeed such "separation" can only be understood as such if we treat the seas encompassing our island as a resource of disconnection from other lands. But if we use the sea as an affordance to boat over to a mainland, our island's separation or "boundedness" becomes incorporated by a boat's wake ${ }^{44}$. It is through these practices of movement that we dwell a particular place.

As Ingold ${ }^{45}$ notes, the forms of place that people build "arise within the current of their involved activity, in the specific relational contexts of their practical engagement with their surroundings." Islandness, therefore, is a never-ending relational project transcending any sort of finiteness, separation and clear boundedness ${ }^{46}$. A particular island cannot be said to have more or less islandness. To suggest that then we would have to agree that islandness is a completed project, a threshold of sorts, which islanders may or may not be able to approximate. But islandness always goes on, in different ways, on every island, for as long as people dwell there and shape that island through their own unique practices.

An island, again extrapolating from Ingold 47 "owes its character to the experiences it affords to those who spend time there- to the sights, sounds, and indeed smells that constitute its specific ambience. And these in turn depend on the kinds of activities in which its inhabitants engage." Through the passage of time these activities constitute islandness as both a fleeting and a more enduring record. A deer temporarily resting in the middle of unpaved road is a fleeting record, for example. But that paved road and the deer trail leading to it are more enduring traces. These landscapes of movement, rest, and encounter become part of inhabitants' lives. Just as the deer gathers a pathway through the bushes by co-opting the spaces left open by vegetation, islanders gather friends together as they walk to the grocery store or the coffee shop to collect supplies and share stories about common island life ${ }^{48}$. Through these and other processes of gathering through movement, rest, and encounter places become what they are, and dwellers also become who they are. Islanders and islands imply one another, and that implication is islandness itself, a mutual, relational "incorporation" 49 of body and place, a movement wherein the forms of islands and islanders are generated. 
Through these processes of incorporation islanders attend to their everyday living as a set of dwelling tasks, like catching the ferry, driving to the other end, walking to the store, paddling to enjoy quality time together. These tasks often differ from those typical of many urban places and mainland locations-which may not feature the mobility scapes (e.g. seaplanes, kayak and ferry routes, waterfront promenades, tidal areas, etc.) common on many islands. Thus in engaging these features of places islanders effectively confront a taskscape $e^{50}$ that is relatively unique to many islands, unique enough to guarantee a sense of islandness to the place. Tasks are practical orientations to action, taking their significance in relation to other tasks, the resources and tools available to perform, and the orientations and skills of their performers-amongst many other elements. Tasks also always unfold within a place, thus essentially presenting themselves to us as a taskscape-such as strategically leaving a home five minutes earlier than normal to beat summer Sunday morning ferry traffic.

The unique challenges presented by these kinesthetic tasks, the relatively unique styles, tools, resources, and rhythms through which inhabitants tackle their tasks gives rise to relatively unique taskscapes. Thus different islands are but different taskscapes, requiring and enabling different kinds of movements with different rhythms, speeds, durations, frictions, motives, costs, routes, feels, and degrees of remove from "the mainland"51. Through the constant unfolding of these taskscapes, from site to site, islandness is never finished, never complete, and never uniform—always a meshwork of interweaving tasks and patterns. Thus islandness lies not in any particular combination of rhythm, speed, or any particular element or in any one kind of taskscape, but rather in the meshwork of interrelated practices of which your island is made. Through these dwelling practices your island comes to be what it is, subject to the improvised performances of its dwellers. Through these performances we inhabit our islands, moving along with them, taking part in the world's transformation of itself 52 .

By "moving along with them" I do not mean to suggest that the tectonic plates on which islands rest move. Certainly those do, and plenty of geological research would show just that, but my argument is different. By suggesting that islands are what its inhabitants do, that islands are dynamic dwellings, that they are taskscapes, and that they are the outcomes of practices of creative incorporation in which human and non-human dwellers engage, I have made the argument that islands are fields of relations, socio- 
environmental-technical relations to be navigated ${ }^{53}$. Thus it makes sense to say that, like other places, islands "do not have locations but histories" 54 , and that "bound together by the itineraries of their inhabitants [islands] exist not in space but as nodes in a matrix of movement" 55 . To be sure, we are able to track the location of an island by its longitude and latitude, just like we are able to measure its size and population density. But these spatial patterns, while of importance, do not reveal everything about islandness. An island's geographic location, size, and population are material features that islanders incorporate into their journeys to, from, and within islands-journeys that distinguish some islanders from some mainlanders, and islanders from other islanders ${ }^{56}$. In other words, these material features do not determine islandness. Rather they work as affordances for their inhabitants' actions.

Like other dwellers of other places, islanders are often on the move ${ }^{57}$. Travelling plays a part in shaping the traveler. And just like the traveler and her path are one of the same, an islander and his island are one of the same, and that ongoing performative, kinesthetic process of action and interaction is islandness ${ }^{58}$. To outsiders islanders' paths may be barely perceptible, but to local inhabitants routine movements become natural, habitual, and eventually etched in personal and collective memories and histories of place. Moving, writes Ingold ${ }^{59}$, thus works like a form of storytelling. "Ever attentive to wind and weather, to swell and tide, to the flight of birds and a host of other signs, the experienced mariner can guide his [sic] ship through the deepest of waters without having to resort to instruments of any kind"60 and thus sense of place becomes a kinesthetic performance, as the mariner "watches, listens, and feels as he goes, his entire being alert to the countless cues that, at every moment, prompt the slightest adjustments to his bearing" 61 . And this, in sum, is how an islander's movement becomes part of her sense of place, of her place itself, and in the end of her own body and self and way of life. Like a form of affect, islandness thus consists of this islander's sense of place, of this island's ways of being, of acting, of moving around, or resting, of encountering others, of the capacity to affect an island lifeworld and be affected by it. Like a way of being and becoming gendered, islandness works as an open project, subject to the creativity of those who fashion it together by assembling different resources with different techniques and purposes. Like "man," or "woman" "islandness" is not easily defined. It takes as many different forms as there are islands" ${ }^{2}$ and we ought to be glad it does. 


\section{Acknowledgment}

This research was made possible through funding from the Canada Research Chair program. We also wish to thank Tim Cresswell, Godfrey Baldacchino, Eric Clark, and the anonymous reviewers for their kind feedback.

\section{Biographical Notes}

Phillip Vannini is Canada Research Chair in Innovative Learning and Public Ethnography (www.publicethnography.net) and Professor in the School of Communication and Culture at Royal Roads University in Victoria, Canada. He is author/editor of nine books, including Ferry Tales: Mobility, Place, and Time on Canada's West Coast (Routledge, 2012) and Popularizing Research: Engaging New Media, New Genres, New Audiences (Peter Lang, 2012).

Jonathan Taggart is a Vancouver-based photojournalist and graduate student in Intercultural and International Communication at Royal Roads University who specializes in social documentary, editorial photography, visual advocacy, and visual ethnography (www.jonathantaggart.com)

\section{Notes}

\footnotetext{
1 "I" refers to the first author.

2 P. Hay, 'A Phenomenology of Islands', Island Studies Journal, 1, 2006, pp. 19-42.

${ }^{3}$ S. Jackson and S. Scott (Eds.), Gender: A Sociological Reader (London: Routledge, 2001).

${ }^{4}$ G. McCall, 'Nissology: A Proposal for Consideration', Journal of the Pacific Society, 63/64, 1994, pp. 98-106.

${ }^{5}$ Hay, 'A Phenomenology of Islands', p. 34.

${ }^{6}$ F. Peron, 'The Contemporary Lure of the Island', Tijdschrift Voor Economische en Sociale Geographie, 95, 2004, pp. 326-339, p. 326.

7 D.D. Platt. 'Islandness', in P. Conkling, D.D. Platt, (eds), Holding Ground: The Best of Island Journal, 1984-2004. (Rockland, Maine: Island Institute, 2004), pp. 1-25, p. 1.

${ }^{8}$ J.R. Gillis, How the Human Imagination Created the Atlantic World (London: Palgrave, 2009).

${ }^{9}$ E. Hughes, Study of a Secular Institution: The Chicago Real Estate Board (PhD. Dissertation, Department of Sociology, University of Chicago, 1928).

${ }^{10}$ T. Ingold, The Perception of the Environment: Essays in Livelihood, Dwelling, and Skill (London: Routledge, 2000).

${ }^{11}$ P. Cloke, O. Jones, 'Dwelling, Place, and Landscape: An Orchard in Somerset', Environment \& Planning A, 33, 2001, pp. 649-666.

${ }^{12}$ M. deCerteau, The Practice of Everyday Life (Berkeley: University of Califonia Press, 1984).

${ }^{13}$ D. Seamon, A Geography of the Lifeworld (New York: Palgrave, 1979).

${ }^{14}$ T. Ingold, Lines: A Brief History (London: Routledge, 2007); also see Ingold, The Perception of the Environment.

${ }^{15}$ For literature reviews see H. Lorimer, 'Cultural Geography: The Busyness of Being 'More-thanRepresentational', Progress in Human Geography, 29, 2005, pp. 83-94; H.Lorimer, 'Cultural Geography: Worldly Shapes, Differently Arranged', Progress in Human Geography, 31, 2007, pp. 89-100. H. Lorimer, 'Cultural
} 
Geography: Non-Representational Conditions and Concerns', Progress in Human Geography, 32, 2008, pp. 551559.

${ }_{16}$ See. B. Anderson, P. Harrison (Eds.), Taking-Place: Non-Representational Theories and Geography (Burlington, VT: Ashgate, 2010); N. Thrift, Spatial Formations (London: SAGE, 1996); N. Thrift, Non-Representational Theory (London: Routledge, 2008).

${ }^{17}$ I have intentionally avoided the writing of a background section in which basic facts about Gabriola Island are outlined because I do not want to reproduce the ideology that a place can be apprehended by revealing the objective characteristics that make it a particular geographical site. The interested reader is invited to search for such basic information online. Let it suffice to say here that Gabriola Island is located in the Salish Sea twenty-five minutes away from Nanaimo on Vancouver Island, and twenty-five minutes away by seaplane from Vancouver, British Columbia, Canada.

${ }^{18}$ Due to lack of space in this paper I do not discuss additional important aspects of island mobilities, such as tourism, migration, and connectivity. While these are important mobile practices which clearly contribute to islandness I find that they are different types of kinesthetic practices than the ones that attract my attention and that they are already well discussed elsewhere. See for example A. Christensen, O. Mertz, O., 'Researching Pacific Islands Livelihoods: Mobility, Natural Resource Management, and Nissology', Asia Pacific Viewpoint, 51, 2010, pp. 278-287; S. Royle, A Geography of Islands: Small Island Insularity (London: Routledge, 2001); M. Sheller, 'Virtual Islands: Mobilities, Connectivities, and the New Caribbean Spatialities', Small Axe, 24, 2007, pp. 16-33.

19 P. Conkling, 'On Islanders and Islandness', The Geographical Review, 97, 2007, pp. 191-201, p. 200; also see G. Baldacchino, 'Islands-Objects of Representation', Geografiska Annaler, 87B, 2005, pp. 247-251.

${ }^{20}$ See N. Thrift, J.D. Dewsbury, 'Dead Geographies and How to Make Them Live', Environment and Planning $D, 18,2000$, pp. 411-432.

${ }^{21}$ L. Neilsen, 'Lyric Inquiry', in G. Knowles, A. Cole, (eds), Handbook of the Arts in Qualitative Inquiry (Thousand Oaks, CA: Sage, 2008) pp. 93-101.

22 A. Cole, G. Knowles, 'Arts-Informed Research', in G. Knowles, A. Cole, (eds), Handbook of the Arts in Qualitative Inquiry (Thousand Oaks, CA: Sage, 2008) pp. 55-70.

${ }^{23} \mathrm{~K}$. Stewart, A Space on the Side of the Road (New York: Princeton University Press, 1996).

${ }^{24}$ For more on this methodological approach see S. Pink, Doing Sensory Ethnography (London: SAGE, 2009).

25 After J. Wylie, 'An Essay on Ascending Glastonbury Tor', Geoforum, 33, 2002, pp. 441-454; J. Wylie, 'A Single Day's Walking: Narrating Self and Landscape on the South West Coast Path', Transactions of the Institute of British Geographers, 30, 2005, pp. 234-247.

${ }^{26}$ Identifying reference.

27 The issue of "who islanders are" is of importance, and deserves a reflection. It is not my intention to imply that the only "authentic" islanders are full-time residents. Indeed, it is not my intention to have my argument hinge on islanders' identities at all. In Lines Ingold makes the point that we should not distinguish between wayfarers on the basis of an assumption of bounded space. He suggests that movements intersect with other movements, creating meshworks that are not bound by finite spaces. Relatedly, he argues, we should not speak of locals and outsiders, but rather of inhabitants. Inhabitants are wayfarers who create a place through their movements. Following that argument I use the world "islanders" to refer to those who move about an island-regardless of where they come from. For a more in-depth look at the basis of this argument see Ingold, Lines, pp. 100-101.

${ }^{28}$ However performative that may be, e.g. M. Gibbons, 'Islanders in Community: Identity Negotiation through Sites of Conflict and Transcripts of Power', Island Studies Journal, 5, 2010, pp. 165-192.

${ }^{29}$ Royle, A Geography of Islands: Small Island Insularity.

30 This argument incidentally addresses the question of how an island without human residents constitutes an island too. To suggest that "inhabitants" practices and movements generate an island does not imply that those inhabitants must be human.

${ }^{31}$ Ingold, The Perception of the Environment, p. 3.

32 Seamon, A Geography of the Lifeworld. 
${ }^{33}$ For a related but theoretically different argument on islandness as sense of place see E. Stratford, 'Islandness and Struggles over Development: A Tasmanian Case Study', Political Geography, 25, 2008, pp. 160175.

${ }^{34}$ Ingold, The Perception of the Environment, p. 20.

${ }^{35}$ For example see Stratford, 'Islandness and Struggles over Development'.

${ }^{36}$ Ingold, The Perception of the Environment, p. 23.

${ }^{37}$ Ingold, The Perception of the Environment, p. 153.

${ }^{38}$ Ingold, The Perception of the Environment, p. 153.

${ }^{39} \mathrm{~J}$. Bonnemaison, 'The Tree and the Canoe: Roots and Mobilities in Vanuatu Societies', Pacific Viewpoint, 26, 1985, pp. 30-62

${ }^{40}$ K. Olwig, 'Are Islanders Insular? A Personal View', The Geographical Review, 2, 2007, pp. 175-190.

${ }^{41}$ Though they may, at times, leave temporary or permanent traces, e.g. G. Baldacchino (Ed.), Bridging Islands: The Impact of Fixed Links (Charlottetown, PEI: Acorn Press, 2007); O. Lofgren, 'Island Magic and the Making of a Transnational Region', The Geographical Review, 97, 2007, pp. 244-259.

42 Ingold, The Perception of the Environment.

${ }^{43}$ See identifying reference; also see Baldacchino, Bridging Islands; Peron, 'The Contemporary Lure of the Island'.

${ }^{44}$ For a related argument see E. Hau'ofa, 'Our Sea of Islands', The Contemporary Pacific, 6, 2003, pp. 148161; P. Hay, 'A Phenomenology of Islands', Island Studies Journal, 1, 2006, pp. 19-42; K.F. Olwig, 'Islands as Places of Being and Belonging', The Geographical Review, 2,2007, pp. 260-273.

45 Ingold, The Perception of the Environment, p. 186.

${ }^{46}$ E. Stratford, 'Editorial: Flows and Boundaries: Small Island Discourses and Challenges of Sustainability, Community, and Local Environments', Local Environment, 8, 2003, pp. 495-499, p. 495.

47 Ingold, The Perception of the Environment, p. 192

48 On islandness as an outcome of orality see N. Bethel, 'Navigations: Insularity Versus Cosmopolitanism in the Bahamas: Formality and Informality in an Archipelagic Nation', Social Identities, 8, 2002, pp. 237-253.

${ }^{49}$ Ingold, The Perception of the Environment, p. 193.

50 Ingold, The Perception of the Environment, p. 195.

${ }^{51}$ See identifying reference; also see T. Cresswell, 'Towards a Politics of Mobility', Environment \& Planning D, 28, 2010, pp. 17-31; Lofgren, 'Island Magic and the Making of a Transnational Region.'

52 Ingold, The Perception of the Environment, p. 200.

${ }^{53} \mathrm{~K}$. Olwig, 'Are Islanders Insular?'

${ }^{54}$ Ingold, The Perception of the Environment, p. 219.

55 Ingold, The Perception of the Environment, p. 219.

${ }^{56} \mathrm{~K}$. Olwig, 'Are Islanders Insular?'

${ }^{57}$ e.g. see M. Jolly, 'On the Edge? Deserts, Oceans, Islands', The Contemporary Pacific, 13, 2001, pp. 417-466;

K.F. Olwig, 'Islands as Places of Being and Belonging'; Sheller, 'Virtual Islands'.

${ }^{58} \mathrm{~K}$. Olwig, 'Are Islanders Insular?'

${ }^{59}$ Ingold, Lines.

${ }^{60}$ Ingold, Lines, p. 76.

${ }^{61}$ Ingold, Lines, p. 78.

${ }^{62}$ J.R. Gillis, D. Lowenthal, 'Introduction', The Geographical Review, 97, 2007, pp. iii-vi, p. iii. 